DOI: 10.20472/IAC.2019.045.026

\title{
COLIN MURPHY
}

Department of Construction Economics, University of Pretoria, South Africa

\section{CHRIS CLOETE}

Department of Construction Economic, University of Pretoria, South Africa

\section{DEBT CAPITAL MARKETS AS A FUNDING SOURCE FOR LISTED PROPERTY FUNDS IN SOUTH AFRICA}

\begin{abstract}
:
Purpose of paper

Property finance in South Africa has traditionally been a market dominated by bank lend-ing. However in the context of the Basel III Accord creating cost and other regulatory impli-cations for bank lending, as well a maturing listed property market adopting international best practice in the form of REIT legislation, debt capital markets funding is becoming a significant component of REITs' capital structure. The study seeks to determine the merits and impact of this nascent funding source for REITs in South Africa.

Methodology

Following a review of applicable literature, interviews with senior management of nine listed property funds and other debt capital markets stakeholders were undertaken. Cer-tain advantages and disadvantages of debt capital markets funding, in comparison to other lending sources, were presented as hypotheses to the interviewees.

Findings

The responses show support from a significant majority of the interviewees for four partic-ular advantages and two disadvantages. The study also found support for these ad-vantages and disadvantages to be transient.

Value of paper

It is advised that REITs periodically reassess the respective advantages and disadvantages of this funding source for their business.
\end{abstract}

\section{Keywords:}

REIT; Basel III; debt capital funding

JEL Classification: G30, G23, G19 


\section{INTRODUCTION}

The property finance market in South Africa ("SA") has historically been the preserve of the SA banks, with property finance loans, secured by mortgage bonds over the subject properties, being the principal product offered. Table 1 sets out the lending landscape (participants and market share) for property finance amongst commercial banks.

In recent years, notably from 2010 onwards, a number of new facets to the property finance market emerged. Undoubtedly the impact of the Basel III regulations ("B III"), implemented post the 2008 global financial crisis, have led to a change in the manner in which banks are capitalised and the manner in which they source the required liquidity to provide loans to the borrower.

The primary drivers of the Basel III Accord are:

- Net Stable Funding Ratio ("NSFR") - Intended to promote a more stable funding structure for banks (reduce dependency on short term wholesale funding). Stable funding is defined as contractually long-term funding ( $>12$ months remaining maturity). Measured as: Available amount of stable funding/Required amount of stable funding (BCBS, 2014:2). There is a marked shortage of these high quality liquid assets in certain countries, including SA, (Bech \& Keister, 2014:3) and, as such, the supply and demand dynamics are driving up the cost of borrowing.

- Liquidity Coverage Ratio ("LCR") - Intended to ensure banks have enough high quality liquid assets ("HQLA") to protect against a short term liquidity shock. Measured as: Stock of high quality liquid assets/Net cash outflows over a 30 day period (BCBS, 2013:4)

Table 1: BA900 Market Share $2012-2016$

BA900 Market Share

\begin{tabular}{|l|l|l|l|l|l|l|l|l|l|l|}
\hline \multirow{2}{*}{ Bank } & \multicolumn{2}{l}{ Dec-12 } & \multicolumn{2}{l}{ Dec-13 } & \multicolumn{2}{l|}{ Dec-14 } & \multicolumn{2}{l|}{ Dec-15 } & \multicolumn{2}{l|}{ Dec-16 } \\
\cline { 2 - 12 } & R'000 & $\%$ & $R^{\prime} 000$ & $\%$ & $R^{\prime} 000$ & $\%$ & $R^{\prime} 000$ & $\%$ & $R^{\prime} 000$ & $\%$ \\
\hline ABSA & 42 & $17 \%$ & 39 & $15 \%$ & 37 & $13 \%$ & 41 & $12 \%$ & 39 & $11 \%$ \\
\hline FirstRand & 14 & $6 \%$ & 13 & $5 \%$ & 19 & $6 \%$ & 20 & $6 \%$ & 22 & $6 \%$ \\
\hline Investec & 50 & $20 \%$ & 49 & $19 \%$ & 54 & $18 \%$ & 63 & $19 \%$ & 69 & $19 \%$ \\
\hline Nedbank & 97 & $38 \%$ & 103 & $40 \%$ & 121 & $41 \%$ & 134 & $41 \%$ & 149 & $41 \%$ \\
\hline Standard & 45 & $18 \%$ & 49 & $19 \%$ & 57 & $19 \%$ & 65 & $20 \%$ & 75 & $21 \%$ \\
\hline Other & 5 & $2 \%$ & 6 & $2 \%$ & 7 & $2 \%$ & 8 & $2 \%$ & 8 & $2 \%$ \\
\hline Total per BA 900 & 253 & & 259 & & 295 & & 331 & & 362 & \\
\hline
\end{tabular}

Source: data per South African Reserve Bank, 2017 and SBG Securities, 2015 
With the above structural changes in bank funding parameters, new aspects to the property finance market have been observed. This includes the emergence of Non-Bank Financial Institutions ("NBFI's") - such as life assurance companies and asset managers that seek to hold fixed income investments (including corporate debt) as well as the Debt Capital Markets ("DCM") that has shown itself to be a well-supported platform offering an efficient means of funding for both corporates and state-owned enterprises. Total annual credit issuance has grown from annual levels of below R30 million per annum in 2004 to above R100 million per annum for calendar years from 2012 onwards (Standard Bank Research, 2017b).

Listed property companies have focussed on the DCM to introduce a new funding source to their capital structure. Table 2 illustrates the growth in DCM activity by listed property entities (bond and commercial paper ("CP") - outstanding balances as at 31 Dec) while Table 3 illustrates the composition of debt funding for all listed property funds that have a DCM programme in place as at 31 December 2016:

Table 2: Outstanding Property DCM Issuance

\begin{tabular}{|l|l|l|l|l|}
\hline Year & Bond Issuance & Commercial paper & Total & $\%$ growth \\
\hline $\mathbf{2 0 1 0}$ & $500,000,000$ & $835,000,000$ & $1,335,000,000$ & \\
\hline $\mathbf{2 0 1 1}$ & $3,485,000,000$ & $2,175,000,000$ & $5,660,000,000$ & $324 \%$ \\
\hline $\mathbf{2 0 1 2}$ & $8,764,000,000$ & $5,102,000,000$ & $13,866,000,000$ & $145 \%$ \\
\hline $\mathbf{2 0 1 3}$ & $13,595,000,000$ & $5,905,000,000$ & $19,500,000,000$ & $41 \%$ \\
\hline $\mathbf{2 0 1 4}$ & $18,427,000,000$ & $5,982,000,000$ & $24,409,000,000$ & $25 \%$ \\
\hline $\mathbf{2 0 1 5}$ & $18,738,500,000$ & $3,029,000,000$ & $21,767,500,000$ & $-11 \%$ \\
\hline $\mathbf{2 0 1 6}$ & $24,273,500,000$ & $2,047,000,000$ & $26,320,500,000$ & $21 \%$ \\
\hline
\end{tabular}

Source: data per Standard Bank Research, 2017b 
Table 3: Listed Property Funds - Lending composition

DCM Proportion - Listed Property Funds with DCM programmes -Dec 16

\begin{tabular}{|c|c|c|c|c|c|c|}
\hline $\begin{array}{l}\text { Listed Property } \\
\text { Fund }\end{array}$ & Bond & CP & Total DCM & Total Debt & $\begin{array}{c}\% \\
\text { DCM }\end{array}$ & Market Cap \\
\hline \multicolumn{7}{|l|}{ Accelerate Property } \\
\hline Fund & 1226000000 & - & 1226000000 & 3706014000 & $33.1 \%$ & 6501530000 \\
\hline & & & & & & \\
\hline Delta Property Fund & 687000000 & - & 687000000 & 5004118000 & $13.7 \%$ & 5791650000 \\
\hline Emira Property Fund & 1687000000 & 254000000 & 1941000000 & 5377609000 & $36.1 \%$ & 7351920000 \\
\hline Fortress Income Fund & 1445500000 & 376000000 & 1821500000 & 14499295000 & $12.6 \%$ & 57266620000 \\
\hline Growthpoint Properties & 5524000000 & 352000000 & 5876000000 & 31168000000 & $18.9 \%$ & 74432060000 \\
\hline \multicolumn{7}{|l|}{ Hospitality Property } \\
\hline Fund & 970000000 & - & 970000000 & 1725492000 & $56.2 \%$ & 4537900000 \\
\hline & 1 & 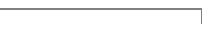 & & & & \\
\hline Hyprop Investments & 2300000000 & - & 2300000000 & 9138496000 & $25.2 \%$ & 29815440000 \\
\hline & 1 & & & & & \\
\hline Investec Property Fund & 2081000000 & 241000000 & 2322000000 & 5539207000 & $41.9 \%$ & 10953540000 \\
\hline Octodec Investments & 379000000 & 347000000 & 726000000 & 4779027000 & $15.2 \%$ & 6025870000 \\
\hline & 1 & & & & & \\
\hline Rebosis Property Fund & 330000000 & 10000000 & 340000000 & 6140810000 & $5.5 \%$ & 7673170000 \\
\hline & & & & & & \\
\hline Redefine Properties & 4226000000 & 150000000 & 4376000000 & 28190102000 & $15.5 \%$ & 62076300000 \\
\hline & & & & & & \\
\hline Resilient REIT & 2388000000 & 100000000 & 2488000000 & 9742843000 & $25.5 \%$ & 47051770000 \\
\hline & 1 & & & & & \\
\hline \multirow[t]{3}{*}{ Vukile Property Fund } & 1030000000 & 217000000 & 1247000000 & 4316038000 & $28.9 \%$ & 13125260000 \\
\hline & & & & & & \\
\hline & 24273500 & & 26320500 & & & \\
\hline Grand Total & 000 & 2047000000 & 000 & 129327051000 & $20.4 \%$ & 332603030000 \\
\hline
\end{tabular}

Source: data per Standard Bank Research (2017b), REIT annual financial statements (2016a - m) and Catalyst Fund Managers (2017)

The above listed property funds represent $82 \%$ of total market capitalisation (as adjusted below) of the listed property sector on the JSE. This derivation is illustrated below: 


\section{Table 4: Proportion of Listed Property Sector with DCM programmes}

\begin{tabular}{|lc|}
\hline & \\
Listed Property Sector Market Cap - Dec 2016 & 574090770000 \\
Less: International Funds (with Offshore debt) & 166543170000 \\
\hline $\begin{array}{l}\text { Adjusted Sector Market Cap } \\
\text { Market Cap - Funds with DCM programmes (Table } \\
\text { 2) }\end{array}$ & 407547600000 \\
\hline Proportion of Sector with DCM programmes & 332603030000 \\
\hline
\end{tabular}

Source: data per Catalyst Fund Managers, 2017

With $82 \%$ of listed property funds, by market capitalisation (as adjusted), having a DCM programme and this DCM issuance representing $20 \%$ of their total funding, it appears that DCM funding has become a material contributor to listed property funds' capital structure. Accordingly an analysis of the advantages and disadvantages of the DCM as a funding source for listed property funds is necessary.

The question to be examined is thus "What are the advantages and disadvantages of the DCM as a funding source for listed property funds in South Africa?"

To answer the above research question, the following hypotheses were tested:

- H1: The following are advantages of DCM as a funding source (relative to other sources of debt):

- H1.1 Cheap - lowering the fund's average cost of debt

- H1.2 Simpler documentation

- H1.3 Longer debt maturities

- H2: The following are disadvantages of DCM as a funding source (relative to other sources of debt):

- H2.1 Inflexible as regards variations to terms

- H2.2 Volatility of the investor base - and thus uncertainty of availability of the funding source

By drawing from the findings of this study, listed property funds in SA will have information pertaining to some significant positive and negative attributes that a new and growing source of funding has for them. In so doing, listed property funds can better position themselves to respond to these advantages and disadvantages. In addition, investors in these instruments can benefit from the study by critically assessing their own investment criteria against the advantages and disadvantages identified in the 
study and place themselves in a position to improve their standing as a reliable and robust source of funding for the listed property sector. Consequently, benefit to the above parties may be found in improved dialogue that could shape a better outcome for both parties in a nascent funding source for the listed property sector.

The remainder of the article is structured as follows: Firstly it reviews the literature pertaining to the B III developments that can affect REIT funding decisions and secondly the DCM context and how REIT funding decisions and capital structure are shaped. Subsequently the research methodology is introduced and discussed. The findings of the research study are then presented. The paper concludes with a discussion of the findings, implications and aspects for further research.

\section{LITERATURE REVIEW}

The literature review commences by providing a sense of the impact of the development of the various Basel Accords, mostly notably B III, on the lending landscape as it relates to bank funding costs. The literature review continues with an outline of the DCM in SA as well positioning the findings of various authors that have studied the decision making drivers for listed property funds and their capital structures. This section of the literature review identifies research undertaken that studies the reasons why listed property funds make the decisions they do in terms of which types of debt are introduced into their capital structure. That is, what advantages and disadvantages are listed property funds attributing to their various funding sources.

\section{Implications of Basel III Accord}

A number of studies have been conducted to assess and quantify the impact of higher capital requirements as well as the introduction of the global liquidity standard under B III. The findings of these studies and the extent to which they may inform the SA lending context are examined below. In particular the intention is to understand the bank lending framework confronting listed property funds.

When the B III literature is considered in the SA listed property fund context, where gross lending margins for listed property funds are reported to be between 165bps and $195 \mathrm{bps}$ for a 5 year bullet tenor (REIT annual financial statements, 2016a - m)), it becomes clear that increased lending spreads of $25 \mathrm{bps}$ to $45 \mathrm{bps}$ (determined by applying the percentages of $15 \%$ to $23 \%$ per King (2010), in conjunction with the various actual basis point ranges cited by Cohen and Scatigna (2014:3)) for a one percentage point increase in capital ratios, would have a material impact on the cost of funding. This is a critical factor in a sector that is assessed on its ability to provide investors with an escalating income stream.

A point of interest for the SA context is that King (2010:28) emphasises the offering of shorter dated debt by banks as a means of reducing the cost impact of the NSFR. It is noted that this would not likely hold appeal for listed property funds who seek liquidity for growth in the form of medium term bullet profile debt. In addition the associated 
refinance risk of too much short tenor debt is not preferred by listed property fund stakeholders (Moody's Investors Service, 2002:4).

The key points to draw from the literature review as regards the banking environment and B III are that:

- Banks in developed markets appear to require a lower increase in lending spreads to recoup the costs of meeting the B III capital adequacy ratios than those in emerging markets (of which SA is one) (Chun, Kim \& Ko (2012:22), Di Biase (2012:1276), Schanz, Aikman, Collazos, Farag, Gregory \& Kapadia (2011:74));

- Real estate lending is shown to be on the lower end of the lending spread increases required as a result of meeting the capital requirements under B III (Chun et al., 2012:3);

- $S A$ is one of the markets identified as having a shortage of HQLA necessary to meet the LCR (South African Reserve Bank, 2013:4 and Bech \& Keister, 2014:3). The South African Reserve Bank provision of a committed liquidity facility highlights the constraints SA banks face to secure adequate sources of funding to meet the global liquidity standard, suggesting that the cost implications for borrowers are more likely to be material increases of a nature that banks will not absorb; and

- The cost impact of the global liquidity standard on lending spreads appears to be greater than that of the heightened capital requirements. The primary cost driver under the global liquidity standard is the NSFR, with forecast lending spread increases of 20 to $24 \mathrm{bps}$ required to offset the cost of higher levels of longer maturity funding sources (King, 2010:28), Chun et al. (2012:25).

Thus the take away for debt funding for price sensitive listed property funds in an emerging market, is one of a high likelihood of increased lending spreads. In particular the preference to reduce refinance risk with longer dated funding could prove problematic where a market was limited to bank lending as a sole debt source.

\section{Debt Capital Markets and REIT capital structure decisions}

SA has a well-established DCM, with participation across a number of categories including municipalities, SOE's, financial institutions (including banks) and corporates (including listed property funds). The local DCM has outstanding issuance of approximately R 2,4 trillion (Standard Bank Research, 2017b). Leading categories are SA Government bonds at $65.6 \%$ of total issuance, followed by the SOE sector with $11.8 \%$ and the financial sector with $11.7 \%$. 


\section{Figure 1: DCM - Outstanding balance per category}

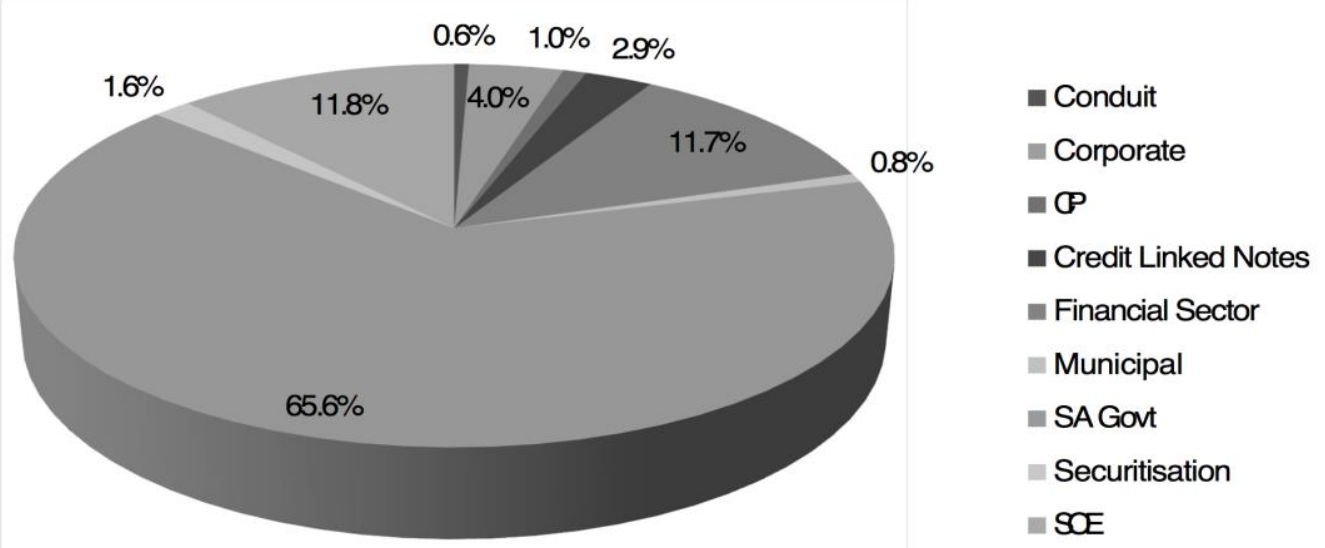

Source: Standard Bank Research, 2017b

The DCM has seen consistent growth in annual issuance since 2000, with 2008 being the only exception. The issuance levels over the past five years (2012 to 2016) have been the highest in the 17 years since 2000 per graph below (Standard Bank Research, 2017b).

Figure 2: DCM - total annual issuance ( $R^{\prime}$ bn) and REIT issuance
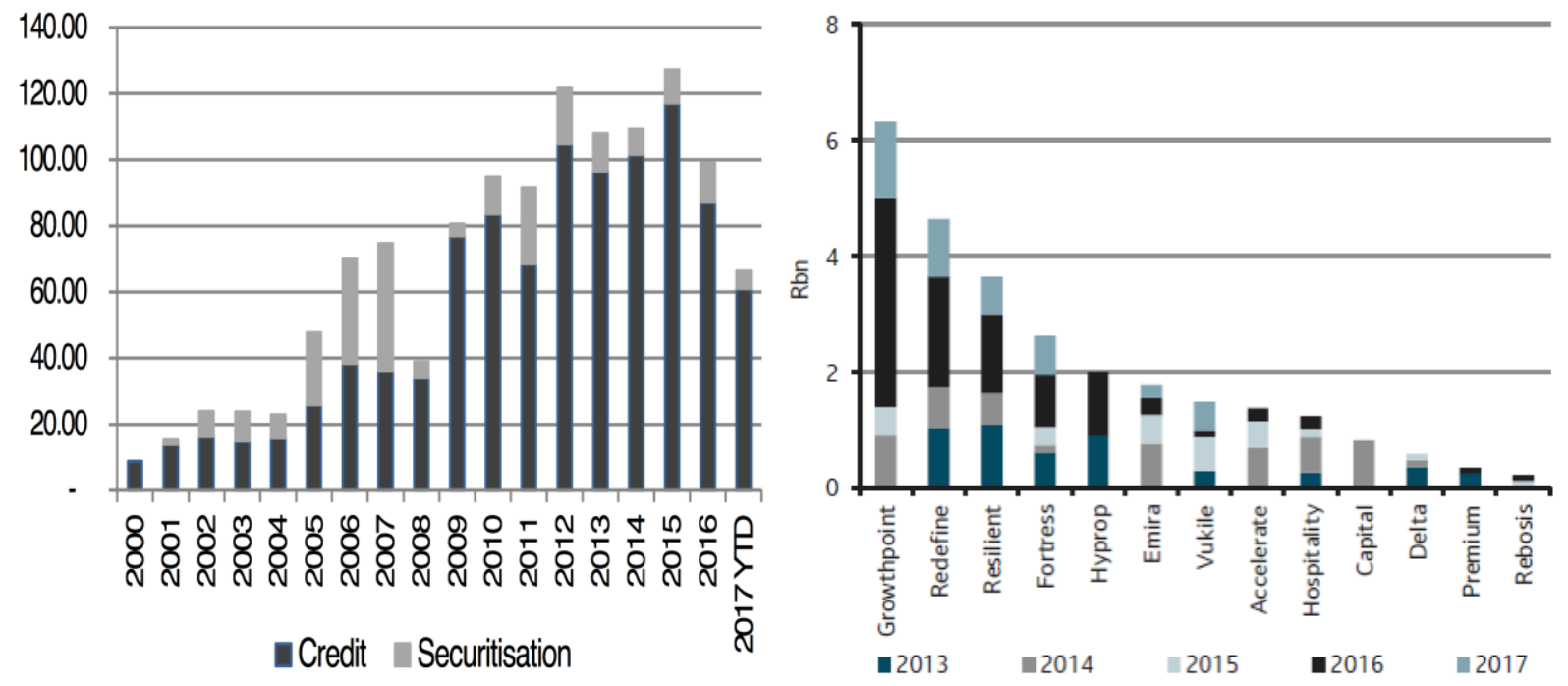

Source: Standard Bank Research, 2017a and b

The property sector constitutes a large and active contributor within the corporate DCM issuer universe, with the property sector's bond issuance, at 31 December 2016, of 
R24.3bn comprising approximately $25 \%$ of the total of R97.8bn in outstanding corporate bonds (Standard Bank Research, 2017b).

Property funds show growing evidence of drawing on the DCM as a funding source, with particular emphasis on short-term funding in the CP market, a segment in which property issuers account for a significant proportion of the total corporate $\mathrm{CP}$ issuance outstanding. Listed property funds comprise 9 out of the 12 corporate issuers with outstanding issuances as at December 2016 (Standard Bank Research, 2017b).

\section{Drivers of REIT capital structure and their associated effects}

The key points to draw from the literature review as regards REIT participation in the DCM and the impact on REIT capital structure are that:

- Most listed property funds in SA have established a DCM programme and this funding source constitutes a material component of total debt funding (Standard Bank Research, 2017b)

- DCM participation is a function of REIT maturity (Hardin III \& Wu, 2010:281)

- An investment grade credit rating is key for DCM participation (Brown \& Riddiough, 2003:315)

- Secured versus unsecured debt plays a meaningful role in REIT funding decisions (Moody's Investors Service, 2002:1)

- Unsecured DCM issuance is seen to allow the issuer to remain flexible and manage its asset decisions with limited, if any, third party intervention (Moody's Investors Service, 2002:3-4)

- REIT funding decisions are a function of market timing and a trade-off between the relative costs of debt and equity funding at the point at which the funding decision is made (Boudry, Kalberg \& Liu, 2010:118 and Feng, Ghosh \& Sirmans, 2007:82)

- Banking relationships can be seen as a facilitator to DCM entry due to the perceived validation and monitoring benefit of this funding source (Hardin III \& Wu, 2010:260)

In summary the following can be gained from the literature review:

- SA has a well-established and growing listed property sector with a track record spanning many years

- SA is adopting international best practise with REIT legislation introduced in May 2013. A number of property funds have completed, or are underway, with their REIT conversion

- SA listed property funds show good credit quality as evidenced by their stable external credit ratings 
- The introduction of B III (as well as the previous accords) has led to an increase in the cost of capital and liquidity for banks, such that a passing on of costs to borrowers appears unavoidable

- A number of studies show differing quantification of this cost, but it is clear that a cost increase will result

- REITs are evaluating and incorporating both secured and unsecured lending in their capital structure. These two forms of debt have discernible pros and cons

- The DCM in SA is a growing source of funding across borrower types, with evidence of strong growth and material representation as a funding source

- It is indicated that listed property funds see the DCM as a lasting, or permanent feature of their capital structure

- It can be shown that the DCM is not a perfect source of funding and that it is susceptible to volatile investor appetite and is meaningfully influenced by externalities. Clearly these attributes of the DCM must have an impact on listed property funds.

Based on the above, there appears to be the following gaps in the available literature:

- A mapping of the advantages and disadvantages of the DCM as a funding source for listed property funds

- The conducting of the above research in the SA context

- An identification of steps (a possible subject for further research) that listed property funds can take to better position themselves to respond to the identified advantages and disadvantages of DCM funding.

\section{METHODOLOGY}

The aim of the research is to determine whether the hypotheses regarding the advantages and disadvantages of DCM as a funding source for listed property funds have any support and can, or cannot, thus be rejected.

To test these hypotheses constitutes an in-depth study that focuses on the findings elicited from the senior management of SA listed property funds as well as industry experts involved in supporting listed property funds to establish and operate their DCM programmes.

In order to achieve adequate sampling of sufficient participants in the listed property sector, with DCM programmes, the following four considerations were assessed:

1) A form of ranking by market capitalisation (as at 31 December 2016) - as a means of assessing the proportion of the sector responding in a certain way this approach also tends to speak to the maturity of the funds in the sector, with the larger funds typically having the longer track records in the sector relative to 
those funds with smaller market capitalisations, which tend to be more recent entrants to the listed property market.

2) The alternative was to focus on the DCM experience of the funds in the form of aggregating the number of years for which their DCM programme has been active and weighting responses on this basis. In the case of years of DCM, each part of a year for which DCM was in issuance, was included as a full year. The basis being that although an issuance may have been, say, in Dec 2010, the lead time, ratings agency interaction and investor road shows would have covered a number of months of the year, such that the experience was being built up in the lead up to the issuance. This is all the more relevant in the instance of the maiden issuance of each fund. The period covered by the study was 2010 to 2016 .

3) The third method considered weighting responses based on the interviewee's proportion of outstanding DCM issuance to the total outstanding REIT sector DCM issuance as at 31 December 2016.

4) The fourth method applied was to weight the responses as a proportion of the total number of interviewees.

The table below sets out the proportion of the universe of 13 listed property funds with DCM programmes and issuance as at 31 Dec 2016 that the achieved sample covers across the four weighting approaches.

Table 5: Determination of sampling coverage

\begin{tabular}{|l|l|l|l|l|}
\hline & $\begin{array}{l}\text { Market capitali- } \\
\text { sation }\end{array}$ & $\begin{array}{l}\text { Years of DCM } \\
\text { Issuance }\end{array}$ & $\begin{array}{l}\text { Proportion of } \\
\text { DCM Issuance } \\
\text { Outstanding }\end{array}$ & $\begin{array}{l}\text { No. of interview- } \\
\text { ees }\end{array}$ \\
\hline Participants & R303.6bn & 50 & R22,002bn & 9 \\
\hline Universe & R332.6bn & 65 & R26,321bn & 13 \\
\hline$\%$ & $91.3 \%$ & $76.9 \%$ & $83.6 \%$ & $69.2 \%$ \\
\hline
\end{tabular}

Source: data from Standard Bank Research, 2017b and Catalyst Fund Managers, 2017

The interviews followed a semi-structured format using the same questions as a basis for each interview and allowed for further opinion and insight to be expressed by the interviewee. This dialogue served to further unlock the reasoning and rationale for the answers provided by the interviewees.

In total eleven interviewees participated in the research. These interviewees included nine REIT executives (the "insiders"), with seven being the CFO or an executive with 
finance responsibilities, and two being CEOs. The "outsiders" comprised the head of a local SA bank's DCM advisory team and an analyst in the SA office of an international ratings agency.

The following questions were posed to all interviewees:

1) Do you think that including DCM funding could lower the average cost of debt funding for a listed property fund?

2) Do you view the DCM documentation as simpler compared to that of private lending sources (bank and NBFl's)?

3) Do you believe that longer term debt could be sourced from the DCM as opposed to the private lending sources?

4) Do you consider the DCM to be less flexible as opposed to private lending sources in terms of variations to the lending terms and conditions?

5) Do you believe the availability of DCM funding to be less stable as opposed to private lending sources?

In order to enhance the validity of the research project, corroboration or convergence between the views of the "insiders" and "outsiders" was assessed as a means of adding a layer of robustness to the research.

\section{FINDINGS}

As a point of departure, the literature review has highlighted certain findings that create some context for the environment in which listed property funds are evaluating their debt funding sources and serve to frame the research question and associated hypotheses. These findings include:

- A developing listed property market in SA that is adopting international best practice in the form of REIT legislation and that is incorporating DCM funding into its debt sources at a growing rate

- B III regulations, in particular the introduction of the NSFR, which are expected to increase the lending spreads charged to borrowers in the years ahead. Thus diversification of funding sources is necessary to ensure that long dated, low cost, reliable funding is available for a listed property sector that needs to distribute a growing income stream

- The differing impact of secured and unsecured debt on a REIT's credit rating as well as the necessity of a strong credit rating to optimise access to various debt sources

- The introduction of listed debt serving to reduce the proportion of secured debt owing and/or extending the maturity profile of the issuer, in that bank debt of sub 
five year tenor is typically replaced with DCM issuances of between five and ten year tenor. Empirically, this extension of the maturity profile does not definitively seem to be the case for listed property funds in SA yet

- The indication that DCM is susceptible to volatile investor appetite and is meaningfully influenced by externalities (such as the ABIL failure in 2014 and the removal of the SA finance minister in 2015 "Nenegate")

\section{Testing of hypotheses - summation of interview responses}

In summary, the responses received on each of the interview questions leads to the following conclusions regarding the hypotheses $\mathrm{H} 1.1$ to $\mathrm{H} 2.2$ (Refer Tables 6, 7 and 8 for calculations):

H.1.1 - All interviewees confirmed that DCM funding can lower the average cost of debt funding for a listed property fund, particularly when including CP in the debt funding structure. The extent to which the average cost of debt funding can be lowered is market dependent. A caveat highlighted was the need for standby facilities to provide a liquidity back-stop for short dated CP issuances. A further point noted was that the DCM programme requires some scale in the issuance levels to absorb the initial set up costs of the programme. Furthermore, despite the negative impact of the ABIL event on DCM pricing and appetite, the hypothesis that DCM funding can lower the average cost of debt funding was still supported in a post-ABIL, post "Nenegate" environment, suggesting this advantage to be quite robust, especially with $\mathrm{CP}$ in the funding mix.

H.1.2 - All interviewees, irrespective of measurement weighting, were in support of the hypothesis that DCM documentation was simpler than that of the private lending sources. The opinions on whether this simplicity was a material advantage of DCM funding reduced to no less than $56 \%$ across the measurements weightings $(60 \%$ on average) being in support of the hypothesis. A common theme emanating from the interviews was the complexity of the initial DCM programme establishment, but the subsequent ease of issuance thereafter. It was also noted that the private lending market was levelling the playing field through the use of a common terms agreement format for loan documentation, also leading to a simplified documentation process for providing further loan facilities to the borrower.

H.1.3 - No more than $44 \%$ of interviewees (with an average of $39 \%$ ), across all measurement weightings, supported the hypothesis that obtaining longer term debt was an advantage of the DCM. A consistent view expressed was that longer term debt should theoretically be possible, as the construct of the DCM caters for this with its long dated parastatal and government issuers as well as the institutional DCM investor base (asset managers and life assurance companies) that should be targeting longer dated assets to match their liabilities. It was noted by certain interviewees that the cost of longer dated debt, may be a reason why yield focussed listed property funds are not actively pursuing the potential tenor benefit available through the DCM. A number of interviewees allude 
to the private placement route as opposed to the Dutch auction route, being the route to use to explore an issuance of a longer tenor.

H.2.1 - In excess of $67 \%$ of interviewees (with an average of $75 \%$ ), across all measurement weightings, supported the hypothesis that the inflexibility of DCM to variations was a disadvantage. Mention was made that a defined point of contact and a strong relationship with the lender was key to ensuring a simple and reliable means of negotiating variation of terms as regards private lending sources. It was noted that although securing a favourable decision for a variation under an existing DCM issuance was possible, both the cumbersome process involved and the potential negative market reaction to such variation were likely to deter issuers.

H.2.2 - All interviewees, irrespective of measurement weighting, were in support of the hypothesis that the DCM is a less stable source of funding relative to private lending sources. Some interviewees challenged the view that DCM availability could be achieved "at a price" in that negative market events had shown that DCM investors could withdraw from the market entirely. In contrast, the relationship with lenders and the nature of their business as real estate financiers, made bank and NBFI lending more stable, although at a price. A further contributor to the instability of DCM funding was the inability to secure an early refinance of an issuance and thus the issuer was vulnerable to the vagaries of the market on the given date of refinance or new issuance.

\section{Further advantages revealed}

In the process of the interviews that formed the basis of the study, certain other advantages and disadvantages outside of those encapsulated in the hypotheses were raised by the interviewees. In particular, two further advantages were supported by sufficient interviewees such that had they been hypotheses to start with, the study would not have shown any basis on which to reject them.

The further advantages are:

Additional advantage 1 - Diversification of funding sources. In what is considered to be a relatively small market for real estate debt sources in SA, having a further alternative to choose from is an advantage. Comments raised included that having DCM as this additional source of funding benefited the listed property funds by simply being a further option, regardless of price, as well as driving some price tension and competition amongst the REIT's debt funding sources.

Additional advantage 2 - Operational flexibility. This advantage covers both the ease of use of the DCM (short time to bring an issuance to market off an existing DCM programme) and the unfettered manner in which it allows the listed property fund to manage its asset base, particularly in the case of unsecured DCM issuances, where no lender consent is required if properties are being disposed of or altered. This advantage is not to be confused with the disadvantage of inflexibility of a DCM note as regards variation of agreed upon terms post issuance, referred to in $\mathrm{H} 2.1$. 
In considering the five hypotheses as well as the two additional advantages presented, the views of the "outsiders" are supportive of the views expressed by the "insiders", i.e. the nine senior management interviewees. A number of similar themes were raised by the "outsiders" such that there is a good indication of convergence of opinions between the "insiders" and "outsiders" which further serves to support the outcome of the testing of the hypotheses.

Note for tables below: Q1 - Q5 denote questions 1 to 5 posed to all interviewees. Add 1 - Add 2 denote additional advantages 1 and 2.

Note for tables below: Responses marked N/M are to be interpreted as: Not Material as an advantage or disadvantage of DCM funding. This indicates that while the respondents may agree with the hypotheses, the aspect covered is not material enough to warrant a specific advantage or disadvantage of DCM funding.

\section{Table 6: Interview responses - By Market Capitalisation}

\begin{tabular}{|c|c|c|c|c|c|c|c|c|c|c|c|c|c|c|}
\hline \multicolumn{15}{|c|}{ By Market Capitalisation } \\
\hline $\begin{array}{l}\text { Listed } \\
\text { Property } \\
\text { Fund }\end{array}$ & Q1 & R ‘000 & $\begin{array}{l}Q \\
2\end{array}$ & $\mathbf{R}$ ‘000 & $\begin{array}{l}Q \\
3\end{array}$ & $\mathbf{R} \times 000$ & Q4 & R ‘000 & Q5 & R ‘000 & $\begin{array}{c}\text { Add } \\
1\end{array}$ & R ‘000 & $\begin{array}{c}\text { Add } \\
2\end{array}$ & R ‘000 \\
\hline $\begin{array}{l}\text { Interviewee } \\
1\end{array}$ & $\begin{array}{l}\mathrm{Ye} \\
\mathrm{s}\end{array}$ & $\begin{array}{r}65015 \\
30\end{array}$ & $\begin{array}{l}\mathrm{N} / \\
\mathrm{M}\end{array}$ & & $\begin{array}{l}N \\
\mathrm{O}\end{array}$ & & $\begin{array}{l}\text { Ye } \\
\mathrm{s}\end{array}$ & $\begin{array}{r}65015 \\
30\end{array}$ & $\begin{array}{l}\text { Ye } \\
\mathrm{s}\end{array}$ & $\begin{array}{r}65015 \\
30\end{array}$ & Yes & $\begin{array}{r}65015 \\
30\end{array}$ & & \\
\hline $\begin{array}{l}\text { Interviewee } \\
2\end{array}$ & $\begin{array}{l}\mathrm{Ye} \\
\mathrm{s}\end{array}$ & $\begin{array}{r}13125 \\
260\end{array}$ & $\begin{array}{l}\mathrm{N} / \\
\mathrm{M}\end{array}$ & & $\begin{array}{l}\mathrm{Y} \\
\mathrm{e} \\
\mathrm{s}\end{array}$ & $\begin{array}{r}13125 \\
260\end{array}$ & $\begin{array}{l}\mathrm{N} / \\
\mathrm{M}\end{array}$ & & $\begin{array}{l}\text { Ye } \\
\mathrm{s}\end{array}$ & $\begin{array}{r}13125 \\
260\end{array}$ & & & Yes & $\begin{array}{r}13125 \\
260\end{array}$ \\
\hline $\begin{array}{l}\text { Interviewee } \\
3\end{array}$ & $\begin{array}{l}\text { Ye } \\
\mathrm{s}\end{array}$ & $\begin{array}{r}62076 \\
300\end{array}$ & $\begin{array}{l}\text { Ye } \\
\mathrm{s}\end{array}$ & $\begin{array}{r}6207630 \\
0\end{array}$ & $\mathrm{~N}$ & & $\begin{array}{l}\text { Ye } \\
\mathrm{s}\end{array}$ & $\begin{array}{r}62076 \\
300\end{array}$ & $\begin{array}{l}\text { Ye } \\
\mathrm{s}\end{array}$ & $\begin{array}{r}62076 \\
300\end{array}$ & Yes & $\begin{array}{r}62076 \\
300\end{array}$ & & \\
\hline $\begin{array}{l}\text { Interviewee } \\
4\end{array}$ & $\begin{array}{l}\mathrm{Ye} \\
\mathrm{s}\end{array}$ & $\begin{array}{r}74432 \\
060\end{array}$ & $\begin{array}{l}\text { Ye } \\
\mathrm{s}\end{array}$ & $\begin{array}{r}74432 \\
060\end{array}$ & $\mathrm{~N}$ & & $\begin{array}{l}\text { Ye } \\
\mathrm{s}\end{array}$ & $\begin{array}{r}74432 \\
060\end{array}$ & $\begin{array}{l}\text { Ye } \\
\mathrm{s}\end{array}$ & $\begin{array}{r}74432 \\
060\end{array}$ & Yes & $\begin{array}{r}74432 \\
060\end{array}$ & Yes & $\begin{array}{r}74432 \\
060\end{array}$ \\
\hline $\begin{array}{l}\text { Interviewee } \\
5\end{array}$ & $\begin{array}{l}\text { Ye } \\
\mathrm{s}\end{array}$ & $\begin{array}{r}7351 \\
920\end{array}$ & $\begin{array}{l}\text { Ye } \\
\mathrm{s}\end{array}$ & 7351920 & $\begin{array}{l}Y \\
\text { e } \\
\text { S }\end{array}$ & $\begin{array}{r}7351 \\
920\end{array}$ & $\begin{array}{l}\text { Ye } \\
\mathrm{s}\end{array}$ & $\begin{array}{r}7351 \\
920\end{array}$ & $\begin{array}{l}\text { Ye } \\
\mathrm{s}\end{array}$ & $\begin{array}{r}7351 \\
920\end{array}$ & Yes & $\begin{array}{r}7351 \\
920\end{array}$ & & \\
\hline $\begin{array}{l}\text { Interviewee } \\
6\end{array}$ & $\begin{array}{l}\text { Ye } \\
\mathrm{s}\end{array}$ & $\begin{array}{r}47051 \\
770\end{array}$ & $\begin{array}{l}\mathrm{N} / \\
\mathrm{M}\end{array}$ & & $\mathrm{N}$ & & $\begin{array}{l}\text { Ye } \\
\mathrm{s}\end{array}$ & $\begin{array}{r}47051 \\
770\end{array}$ & $\begin{array}{l}\text { Ye } \\
\mathrm{s}\end{array}$ & $\begin{array}{r}47051 \\
770\end{array}$ & & & Yes & $\begin{array}{r}47051 \\
770\end{array}$ \\
\hline $\begin{array}{l}\text { Interviewee } \\
7\end{array}$ & $\begin{array}{l}\text { Ye } \\
\mathrm{s}\end{array}$ & $\begin{array}{r}57266 \\
620\end{array}$ & $\begin{array}{l}\mathrm{N} / \\
\mathrm{M}\end{array}$ & & $\begin{array}{l}Y \\
\text { e } \\
\text { S }\end{array}$ & $\begin{array}{r}57266 \\
620\end{array}$ & $\begin{array}{l}\text { Ye } \\
\mathrm{s}\end{array}$ & $\begin{array}{r}57266 \\
620\end{array}$ & $\begin{array}{l}\text { Ye } \\
\mathrm{s}\end{array}$ & $\begin{array}{r}57266 \\
620\end{array}$ & & & Yes & $\begin{array}{r}57266 \\
620\end{array}$ \\
\hline
\end{tabular}




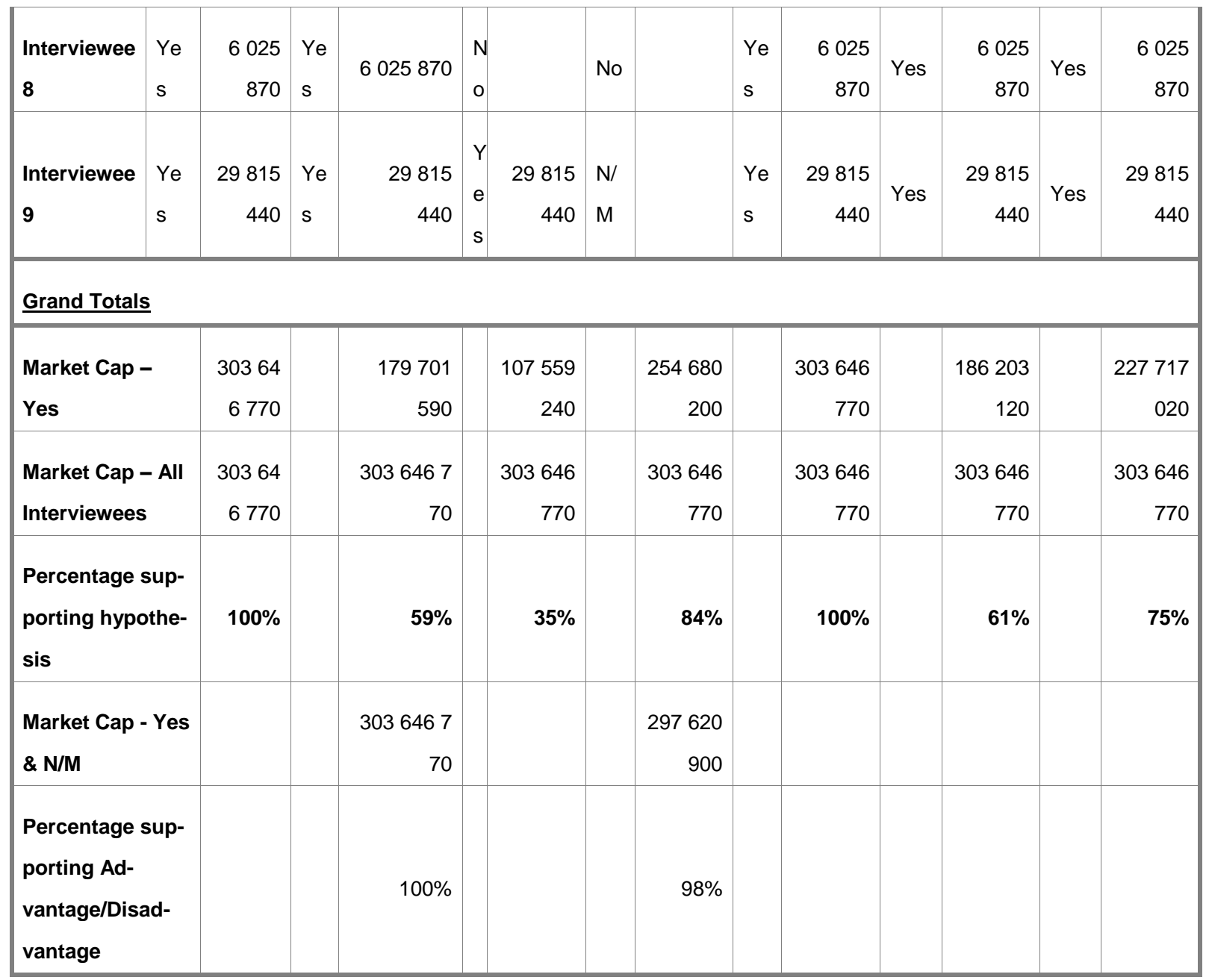

Source: data for weighting approaches from Standard Bank Research, 2017b and Catalyst Fund Managers, 2017

Table 7: Interview responses - By Proportion of DCM Issuance

\begin{tabular}{|c|c|c|c|c|c|c|c|c|c|c|c|c|c|c|}
\hline \multicolumn{15}{|c|}{ By Proportion of DCM Issuance } \\
\hline $\begin{array}{l}\text { Listed Prop- } \\
\text { erty Fund }\end{array}$ & $\begin{array}{l}Q \\
1\end{array}$ & R '000 & $\begin{array}{l}Q \\
2\end{array}$ & R $` 000$ & Q3 & R ‘000 & Q4 & R ‘000 & Q5 & $R ` 000$ & $\begin{array}{c}\text { Add } \\
1\end{array}$ & $\mathbf{R} ‘ 000$ & $\begin{array}{c}\text { Add } \\
2\end{array}$ & R $\mathbf{0 0 0}$ \\
\hline $\begin{array}{l}\text { Interviewee } \\
1\end{array}$ & $\begin{array}{l}Y \\
\text { e } \\
\text { s }\end{array}$ & $\begin{array}{r}1226 \\
000\end{array}$ & $\begin{array}{l}\mathrm{N} / \\
\mathrm{M}\end{array}$ & & No & & $\begin{array}{l}\mathrm{Ye} \\
\mathrm{s}\end{array}$ & $\begin{array}{r}1226 \\
000\end{array}$ & $\begin{array}{l}\text { Ye } \\
\mathrm{s}\end{array}$ & $\begin{array}{r}1226 \\
000\end{array}$ & Yes & $\begin{array}{r}1226 \\
000\end{array}$ & & \\
\hline $\begin{array}{l}\text { Interviewee } \\
2\end{array}$ & $\begin{array}{l}\text { Y } \\
\text { e } \\
\text { s }\end{array}$ & $\begin{array}{r}1247 \\
000\end{array}$ & $\begin{array}{l}\mathrm{N} / \\
\mathrm{M}\end{array}$ & & $\begin{array}{l}\mathrm{Ye} \\
\mathrm{s}\end{array}$ & $\begin{array}{r}1247 \\
000\end{array}$ & $\begin{array}{l}\mathrm{N} / \\
\mathrm{M}\end{array}$ & & $\begin{array}{l}\text { Ye } \\
\mathrm{s}\end{array}$ & $\begin{array}{r}1247 \\
000\end{array}$ & & & Yes & $\begin{array}{r}1247 \\
000\end{array}$ \\
\hline
\end{tabular}




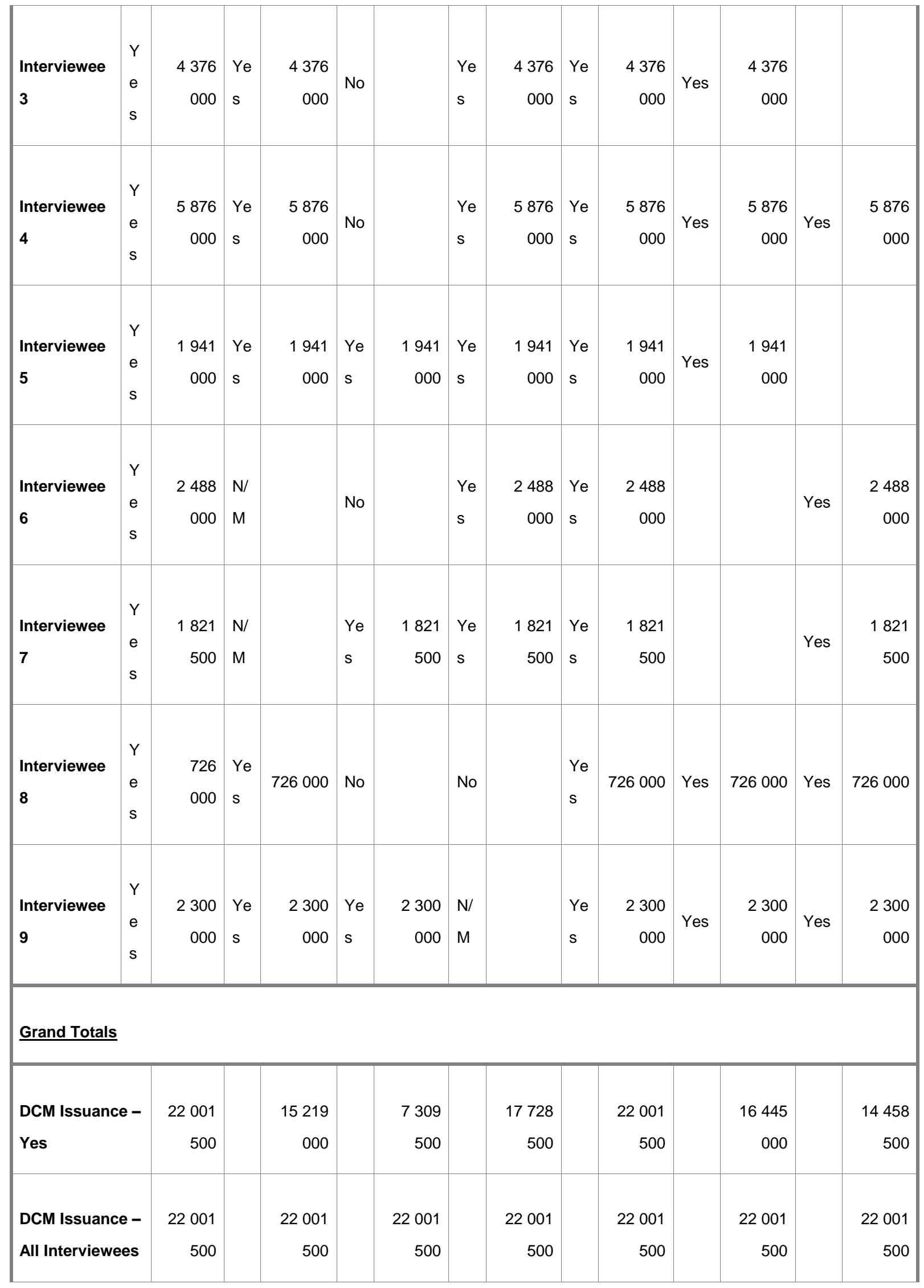




\begin{tabular}{|c|c|c|c|c|c|c|c|}
\hline $\begin{array}{l}\text { Percentage sup- } \\
\text { porting hypoth- } \\
\text { esis }\end{array}$ & $100 \%$ & $69 \%$ & $33 \%$ & $81 \%$ & $100 \%$ & $75 \%$ & $66 \%$ \\
\hline $\begin{array}{l}\text { DCM Issuance - } \\
\text { Yes \& N/M }\end{array}$ & & $\begin{array}{r}22001 \\
500\end{array}$ & & $\begin{array}{r}21275 \\
500\end{array}$ & & & \\
\hline $\begin{array}{l}\text { Percentage sup- } \\
\text { porting Ad- } \\
\text { vantage/Disad- } \\
\text { vantage }\end{array}$ & & $100 \%$ & & $97 \%$ & & & \\
\hline
\end{tabular}

Source: data for weighting approaches from Standard Bank Research, 2017b and Catalyst Fund Managers, 2017

\section{Table 8: Interview responses - By Years of DCM Issuance}

\begin{tabular}{|c|c|c|c|c|c|c|c|c|c|c|c|c|c|c|}
\hline \multicolumn{15}{|c|}{ By Years of DCM Issuance } \\
\hline $\begin{array}{l}\text { Listed Prop- } \\
\text { erty Fund }\end{array}$ & $\begin{array}{l}Q \\
1\end{array}$ & Years & $\begin{array}{l}Q \\
2\end{array}$ & Years & Q3 & Years & Q4 & Years & Q5 & Years & $\begin{array}{c}\text { Add } \\
1\end{array}$ & Years & $\begin{array}{c}\text { Add } \\
2\end{array}$ & Years \\
\hline $\begin{array}{l}\text { Interviewee } \\
1\end{array}$ & $\begin{array}{l}\mathrm{Y} \\
\mathrm{e} \\
\mathrm{s}\end{array}$ & 3 & $\begin{array}{l}\mathrm{N} / \\
\mathrm{M}\end{array}$ & 3 & No & 3 & $\begin{array}{l}\text { Ye } \\
\mathrm{s}\end{array}$ & 3 & $\begin{array}{l}\text { Ye } \\
\mathrm{s}\end{array}$ & 3 & Yes & 3 & & 3 \\
\hline $\begin{array}{l}\text { Interviewee } \\
2\end{array}$ & $\begin{array}{l}\text { Y } \\
\text { e } \\
\text { s }\end{array}$ & 5 & $\begin{array}{l}\mathrm{N} / \\
\mathrm{M}\end{array}$ & 5 & $\begin{array}{l}\text { Ye } \\
\text { s }\end{array}$ & 5 & $\begin{array}{l}\mathrm{N} / \\
\mathrm{M}\end{array}$ & 5 & $\begin{array}{l}\text { Ye } \\
\mathrm{s}\end{array}$ & 5 & & 5 & Yes & 5 \\
\hline $\begin{array}{l}\text { Interviewee } \\
3\end{array}$ & $\begin{array}{l}\mathrm{Y} \\
\mathrm{e} \\
\mathrm{s}\end{array}$ & 6 & $\begin{array}{l}\text { Ye } \\
\mathrm{s}\end{array}$ & 6 & No & 6 & $\begin{array}{l}\text { Ye } \\
\mathrm{s}\end{array}$ & 6 & $\begin{array}{l}\text { Ye } \\
\mathrm{s}\end{array}$ & 6 & Yes & 6 & & 6 \\
\hline $\begin{array}{l}\text { Interviewee } \\
4\end{array}$ & $\begin{array}{l}\mathrm{Y} \\
\mathrm{e} \\
\mathrm{s}\end{array}$ & 7 & $\begin{array}{l}\mathrm{Ye} \\
\mathrm{s}\end{array}$ & 7 & No & 7 & $\begin{array}{l}\text { Ye } \\
\mathrm{s}\end{array}$ & 7 & $\begin{array}{l}\text { Ye } \\
\mathrm{s}\end{array}$ & 7 & Yes & 7 & Yes & 7 \\
\hline $\begin{array}{l}\text { Interviewee } \\
5\end{array}$ & $\begin{array}{l}\text { Y } \\
\text { e } \\
\text { s }\end{array}$ & 6 & $\begin{array}{l}\mathrm{Ye} \\
\mathrm{s}\end{array}$ & 6 & $\begin{array}{l}\text { Ye } \\
\mathrm{s}\end{array}$ & 6 & $\begin{array}{l}\text { Ye } \\
\mathrm{s}\end{array}$ & 6 & $\begin{array}{l}\text { Ye } \\
\mathrm{s}\end{array}$ & 6 & Yes & 6 & & 6 \\
\hline
\end{tabular}




\begin{tabular}{|c|c|c|c|c|c|c|c|c|c|c|c|c|c|c|}
\hline $\begin{array}{l}\text { Interviewee } \\
6\end{array}$ & $\begin{array}{l}\mathrm{Y} \\
\mathrm{e} \\
\mathrm{s}\end{array}$ & 7 & $\begin{array}{l}\mathrm{N} / \\
\mathrm{M}\end{array}$ & 7 & No & 7 & $\begin{array}{l}\text { Ye } \\
\mathrm{s}\end{array}$ & 7 & $\begin{array}{l}\text { Ye } \\
\mathrm{s}\end{array}$ & 7 & & 7 & Yes & 7 \\
\hline $\begin{array}{l}\text { Interviewee } \\
7\end{array}$ & $\begin{array}{l}\mathrm{Y} \\
\mathrm{e} \\
\mathrm{s}\end{array}$ & 6 & $\begin{array}{l}\mathrm{N} / \\
\mathrm{M}\end{array}$ & 6 & $\begin{array}{l}\text { Ye } \\
\mathrm{s}\end{array}$ & 6 & $\begin{array}{l}\text { Ye } \\
\mathrm{s}\end{array}$ & 6 & $\begin{array}{l}\text { Ye } \\
\mathrm{s}\end{array}$ & 6 & & 6 & Yes & 6 \\
\hline $\begin{array}{l}\text { Interviewee } \\
8\end{array}$ & $\begin{array}{l}Y \\
\text { e } \\
\text { s }\end{array}$ & 5 & $\begin{array}{l}\text { Ye } \\
\mathrm{s}\end{array}$ & 5 & No & 5 & No & 5 & $\begin{array}{l}\text { Ye } \\
\mathrm{s}\end{array}$ & 5 & Yes & 5 & Yes & 5 \\
\hline $\begin{array}{l}\text { Interviewee } \\
9\end{array}$ & $\begin{array}{l}\text { Y } \\
\text { e } \\
\text { s }\end{array}$ & 5 & $\begin{array}{l}\text { Ye } \\
\mathrm{s}\end{array}$ & 5 & $\begin{array}{l}\mathrm{Ye} \\
\mathrm{s}\end{array}$ & 5 & $\begin{array}{l}\mathrm{N} / \\
\mathrm{M}\end{array}$ & 5 & $\begin{array}{l}\text { Ye } \\
\mathrm{s}\end{array}$ & 5 & Yes & 5 & Yes & 5 \\
\hline \multicolumn{15}{|l|}{ Grand Totals } \\
\hline $\begin{array}{l}\text { Years of DCn } \\
\text { Yes }\end{array}$ & & 50 & & 29 & & 22 & & 35 & & 50 & & 32 & & 35 \\
\hline $\begin{array}{l}\text { Years of DCn } \\
\text { All Interview }\end{array}$ & & 50 & & 50 & & 50 & & 50 & & 50 & & 50 & & 50 \\
\hline $\begin{array}{l}\text { Percentage s } \\
\text { porting hypo } \\
\text { esis }\end{array}$ & th- & $100 \%$ & & $58 \%$ & & $44 \%$ & & $70 \%$ & & $100 \%$ & & $64 \%$ & & $70 \%$ \\
\hline $\begin{array}{l}\text { Years of DCn } \\
\text { Yes \& N/M }\end{array}$ & & & & 50 & & & & 45 & & & & & & \\
\hline $\begin{array}{l}\text { Percentage s } \\
\text { porting Ad- } \\
\text { vantage/Disa } \\
\text { vantage }\end{array}$ & up- & & & $100 \%$ & & & & $90 \%$ & & & & & & \\
\hline
\end{tabular}

Source: data for weighting approaches from Standard Bank Research, 2017b and Catalyst Fund Managers, 2017 
Table 9: Interview responses - By Number of Interviewees

\begin{tabular}{|c|c|c|c|c|c|c|c|c|c|c|c|c|c|c|}
\hline \multicolumn{15}{|c|}{ By Number of Interviewees } \\
\hline $\begin{array}{l}\text { Listed } \\
\text { Property } \\
\text { Fund }\end{array}$ & Q1 & No. & Q2 & No. & $\begin{array}{l}Q \\
3\end{array}$ & No. & Q4 & No. & Q5 & No. & $\begin{array}{l}\text { Ad } \\
\text { d } 1\end{array}$ & No. & $\begin{array}{l}\text { Ad } \\
\text { d } 2\end{array}$ & No. \\
\hline 1 & Yes & 1 & $\mathrm{~N} / \mathrm{M}$ & - & $\begin{array}{l}\mathrm{N} \\
\mathrm{O}\end{array}$ & - & Yes & 1 & Yes & 1 & Yes & 1 & & - \\
\hline 2 & Yes & 1 & $\mathrm{~N} / \mathrm{M}$ & - & Ye & 1 & $\mathrm{~N} / \mathrm{M}$ & - & Yes & 1 & & - & Yes & 1 \\
\hline 3 & Yes & 1 & Yes & 1 & $\mathrm{~N}$ & - & Yes & 1 & Yes & 1 & Yes & 1 & & - \\
\hline 4 & Yes & 1 & Yes & 1 & $\mathrm{~N}$ & - & Yes & 1 & Yes & 1 & Yes & 1 & Yes & 1 \\
\hline 5 & Yes & 1 & Yes & 1 & $\mathrm{Ye}$ & 1 & Yes & 1 & Yes & 1 & Yes & 1 & & - \\
\hline 6 & Yes & 1 & $\mathrm{~N} / \mathrm{M}$ & - & $\mathrm{N}$ & - & Yes & 1 & Yes & 1 & & - & Yes & 1 \\
\hline 7 & Yes & 1 & $\mathrm{~N} / \mathrm{M}$ & - & Ye & 1 & Yes & 1 & Yes & 1 & & - & Yes & 1 \\
\hline 8 & Yes & 1 & Yes & 1 & $\mathrm{~N}$ & - & No & - & Yes & 1 & Yes & 1 & Yes & 1 \\
\hline 9 & Yes & 1 & Yes & 1 & Ye & 1 & $\mathrm{~N} / \mathrm{M}$ & - & Yes & 1 & Yes & 1 & Yes & 1 \\
\hline \multicolumn{15}{|c|}{ Grand Totals } \\
\hline \multicolumn{2}{|c|}{$\begin{array}{l}\text { No. of Interview- } \\
\text { ees - Yes }\end{array}$} & 9 & & 5 & & 4 & & 6 & & 9 & & 6 & & 6 \\
\hline \multicolumn{2}{|c|}{$\begin{array}{l}\text { No. of Interview- } \\
\text { ees - All Inter- } \\
\text { viewees }\end{array}$} & 9 & & 9 & & 9 & & 9 & & 9 & & 9 & & 9 \\
\hline \multicolumn{2}{|c|}{$\begin{array}{l}\text { \% supporting } \\
\text { hypothesis }\end{array}$} & $\begin{array}{c}100 \\
\%\end{array}$ & & $56 \%$ & & $44 \%$ & & $67 \%$ & & $100 \%$ & & $67 \%$ & & $67 \%$ \\
\hline \multicolumn{2}{|c|}{$\begin{array}{l}\text { No. of Interview- } \\
\text { ees - Yes \& N/M }\end{array}$} & & & 9 & & & & 8 & & & & & & \\
\hline
\end{tabular}




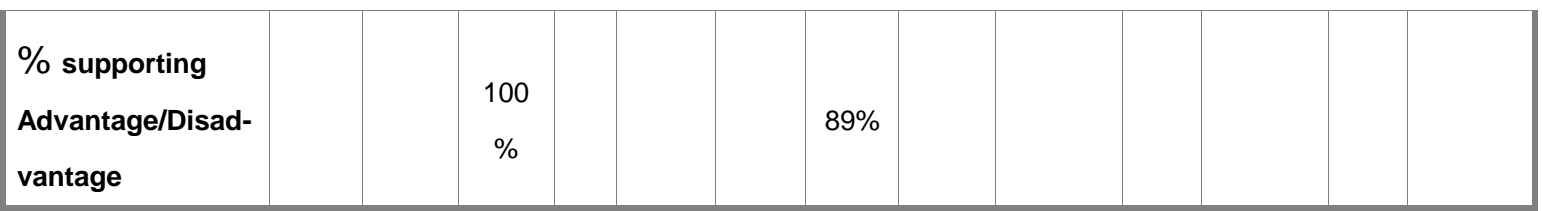

Source: data for weighting approaches from Standard Bank Research, 2017b and Catalyst Fund Managers, 2017

Table 10: Interview responses - range and average and corroborative "outsiders" responses

\begin{tabular}{|c|c|c|c|c|c|c|c|}
\hline $\begin{array}{l}\text { Analysis of Percentage supporting hy- } \\
\text { potheses }\end{array}$ & Q1 & Q2 & Q3 & Q4 & Q5 & Add 1 & Add 2 \\
\hline By Market Capitalisation & $100 \%$ & $59 \%$ & $35 \%$ & $84 \%$ & $100 \%$ & $61 \%$ & $75 \%$ \\
\hline By Proportion of DCM Issuance & $100 \%$ & $69 \%$ & $33 \%$ & $81 \%$ & $100 \%$ & $75 \%$ & $66 \%$ \\
\hline By Years of DCM Issuance & $100 \%$ & $58 \%$ & $44 \%$ & $70 \%$ & $100 \%$ & $64 \%$ & $70 \%$ \\
\hline By Number of Interviewees & $100 \%$ & $56 \%$ & $44 \%$ & $67 \%$ & $100 \%$ & $67 \%$ & $67 \%$ \\
\hline $\begin{array}{l}\text { Maximum percentage supporting hy- } \\
\text { pothesis }\end{array}$ & $100 \%$ & $69 \%$ & $44 \%$ & $84 \%$ & $100 \%$ & $75 \%$ & $75 \%$ \\
\hline $\begin{array}{l}\text { Average percentage supporting hypoth- } \\
\text { esis }\end{array}$ & $100 \%$ & $60 \%$ & $39 \%$ & $75 \%$ & $100 \%$ & $67 \%$ & $69 \%$ \\
\hline $\begin{array}{l}\text { Minimum percentage supporting hy- } \\
\text { pothesis }\end{array}$ & $100 \%$ & $56 \%$ & $33 \%$ & $67 \%$ & $100 \%$ & $61 \%$ & $66 \%$ \\
\hline External 1 & Yes & Yes & Yes & Yes & Yes & & Yes \\
\hline External 2 & & Yes & & Yes & & Yes & \\
\hline
\end{tabular}

\section{DISCUSSION}

The study was intended to answer the following research question: "What are the advantages and disadvantages of the DCM as a funding source for listed property funds in South Africa?"

\section{Research proposition or hypotheses}

To answer the above research question, the following hypotheses were tested: 
- $\mathrm{H} 1$ : The following are advantages of DCM as a funding source (relative to other sources of debt):

- H1.1 Cheap - lowering the fund's average cost of debt

- H1.2 Simpler documentation

- H1.3 Longer debt maturities

- H2: The following are disadvantages of DCM as a funding source (relative to other sources of debt):

- H2.1 Inflexible as regards variations to terms

- H2.2 Volatility of the investor base - and thus uncertainty of availability of the funding source

The above research question and hypotheses were answered and tested through the analysis of the responses to a set of questions put to the interviewees.

The results of the study indicate that hypotheses $\mathrm{H} 1.1, \mathrm{H} 1.2, \mathrm{H} 2.1$ and $\mathrm{H} 2.2$ have strong support and cannot be rejected, while hypothesis $\mathrm{H} 1.3$ has little support and could be rejected.

This suggests that DCM as a funding source:

- Can be a cheap source of funding that can lower a REIT's average cost debt;

- Does offer simpler documentation that that of private lending sources;

- Is inflexible as regards variation to its terms relative to private lending sources;

- Is volatile and lacks the stability of the private lending sources;

- However, does not necessarily result in securing debt of a longer tenor than that achievable from private lending sources.

The literature review uncovered a number of factors affecting the landscape for debt funding to listed property funds. The study finds that these factors, set out below, do permeate the thinking of listed sector senior management when considering the advantages and disadvantages of DCM as a funding source for listed property funds:

- The REIT sector in SA is catching up to its international peer group and can thus start to adopt similar practices of incorporating listed debt as an additional debt source and further diversifier of their capital structure

- The introduction of listed debt, such as DCM issuance, as a funding source is a feature of a maturing REIT market

- Cognisance amongst REIT management of the implications of B III increasing lending spreads for bank debt

- SA property funds see DCM as a permanent feature of their capital structure 
- The SA DCM is vulnerable to negative externalities, as demonstrated by the ABIL event and "Nenegate", and accordingly price and appetite respond to this information

\section{Limitations and assumptions of the study}

The study was limited to SA domiciled listed property funds and to those listed property funds that, at 31 December 2016, had established DCM programmes. It was assumed that the listed fund interviewees were sufficiently unbiased to assess the advantages and disadvantages of their DCM funding activity and that the advantages or disadvantages of the DCM are separately identifiable and not interdependent.

Certain limitations were inherent in the interviewees. A notable differentiator, although difficult to quantify is the differing real estate, finance and in particular, DCM experience of the respective "insiders" and "outsiders". A further intrinsic limitation of the study is that DCM as a REIT funding source is a fairly recent event, with a track record of approximately seven years since 2010 . Notwithstanding, the respective context of a robust DCM over a number of years coupled with the market-negative events in the failure of $A B I L$ and "Nenegate", does create an environment in which the actions and repercussions of the DCM are very topical for REIT senior management.

\section{Aspects for further research}

During the course of the interviews conducted for this research study, certain aspects of the DCM were identified that could be researched in greater detail. Theses aspects are presented below:

1) A study examining secured versus unsecured $D C M$ issuance for listed property funds. Areas to investigate could include the interactions when secured and unsecured DCM issuances are undertaken by the same issuer, as well as what the advantages and disadvantages of each type of issuance are for the issuing property fund. What can also be considered is the rating differential achieved between the secured and unsecured issuance of the same issuer and the impact that the rating of the secured issuance may have on the unsecured rating of the issuer and vice versa.

2) A study examining the merits of a listed property fund following a private placement strategy versus a public auction route when issuing DCM.

3) A case study covering the impact of the ABIL event on the DCM activity of listed property funds in SA. Consideration could be given to facets such as attempting to quantify the movement in pricing and/or issuance size in a pre- and post-ABIL environment.

4) It may be worth revisiting the topic of this research study in future, given that it was the view of a number of the interviewees that the advantages and disadvantages of the DCM as a funding source for listed property funds may change over time. 


\section{Conclusion and recommendation}

Use of the DCM by listed property funds in SA is well established, with approximately $20 \%$ of the debt funding of REITs representing $82 \%$ of the listed property sector by market capitalisation (as adjusted, at the end of December 2016), being in the form of DCM issuance.

The results of the research study show that DCM is an established and viable form of funding that has a role to play in the debt composition of listed property funds in SA. It is clearly revealed that it is imperative that listed property funds understand both the advantages and disadvantages of the inclusion of DCM funding in their capital structure. Furthermore the study highlights that listed property funds need to remain cognisant that the particular advantages and disadvantages applicable to DCM funding for listed property funds are, in some respects, a function of the prevailing circumstances facing both the property sector and the DCM at a point in time. Listed property fund management needs to be alert to continually reassessing the advantages and disadvantages of DCM funding as it pertains to listed property funds in SA.

\section{REFERENCES}

Basel Committee on Banking Supervision (2013) Basel III: The Liquidity Coverage Ratio and liquidity risk monitoring tools. [Online] Available from: http://www.bis.org/publ/bcbs238.pdf

Basel Committee on Banking Supervision (2014) Basel III: the net stable funding ratio. [Online] Available from: http://www.bis.org/bcbs/publ/d295.pdf

Bech, M.L. \& Keister, T. (2014) On the economics of committed liquidity facilities. BIS Working Paper, 439. Bank for International Settlements.

Boudry, W. I., Kallberg, J. G., \& Liu, C. H. (2010). An analysis of REIT security issuance decisions. Real Estate Economics, 38(1), pp. 91-120.

Brown, D. T. \& Riddiough, T. J. (2003) Financing Choice and Liability Structure of Real Estate Investment Trusts. Real Estate Economics, 31 (3), pp. 313-346.

Catalyst Fund Managers (2017) SA Monthly Review - January 2017. Catalyst Fund Managers.

Chun, S. E., Kim, H., \& Ko, W. (2012) The Impact of Basel III Bank Regulation on Lending Spreads: Comparisons across Countries and Business Models. Korea and the World Economy, 13, pp. 351394.

Cohen, B.H. \& Scatigna, M. (2014) Banks and capital requirements: channels of adjustment. BIS Working Paper, 443. Bank for International Settlements.

Di Biase, P. (2012) The Impact Of Basel III On Italian Banks' Loan Rates: An Accounting-Based Approach. International Business \& Economics Research Journal (IBER), 11(11), pp. 1269-1280.

Feng, Z., Ghosh, C., \& Sirmans, C. F. (2007). On the capital structure of real estate investment trusts (REITs). The Journal of Real Estate Finance and Economics, 34(1), pp. 81-105. 
Hardin III, W. G. \& Wu, Z. (2010) Banking relationships and REIT capital structure. Real Estate Economics, 38(2), pp. 257-284.

King, M.R. (2010) Mapping capital and liquidity requirements to bank lending spreads. BIS Working Paper, 324. Bank for International Settlements

Moody's Investors Service (2002) Moody's Views on Secured vs. Unsecured Debt in REITs' Capital Structures. Special Comment, April. New York

REIT Annual Financial Statements (2016) - The following annual and interim financial results (labelled a - m) were sourced for the 13 REIT's with a DMTN programme in place as at 31 December 2016 (Financial results, either interim- or annual results, closest to, but not after 31 December 2016 were chosen):

a. Accelerate Property Fund Limited (2016) Interim financial results for the six months ended 30 September 2016, p. 3.

b. Delta Property Fund Limited (2016) Unaudited condensed consolidated interim results for the six months ended 31 August 2016, p. 3.

c. Emira Property Fund Limited (2017) Unaudited interim financial results for the six months to 31 December 2016, dividend distribution declaration and change in directorate, p. 2.

d. Fortress Income Fund Limited (2017) Condensed unaudited consolidated interim financial statements for the six months ended 31 December 2016

e. Growthpoint Properties Limited (2017) Condensed unaudited results for the six months ended 31 December 2016, p. 14.

f. Hospitality Property Fund Limited (2017) Unaudited condensed consolidated interim results for the six months ended 31 December 2016 and cash dividend declaration, p. 2.

g. Hyprop Investments Limited (2017) Condensed consolidated interim results for the six months ended 31 December 2016, p. 3.

h. Investec Property Fund Limited (2016) Interim results for the six months ended 30 September 2016, p. 4.

i. Octodec Investments Limited (2016) Audited financial statements for the year ended 31 August 2016, p. 9.

j. Rebosis Property Fund Limited (2016) Integrated annual report 2016, p. 99.

k. Redefine Properties Limited (2016) Group annual financial statements 2016, p. 58.

I. Resilient REIT Limited (2017) Condensed unaudited consolidated interim financial statements for the six months ended 31 December 2016.

m. Vukile Property Fund Limited (2016) Unaudited condensed consolidated interim results for the six months ended 30 September 2016, p. 26.

SBG Securities (2015) BA900 regulatory return summary December 2010 to December 2014. [Email to: Murphy, CM 12/02/15] 
Schanz, J., Aikman, D., Collazos, P., Farag, M., Gregory, D. \& Kapadia, S. (2011). The long-term economic impact of higher capital levels. BIS Papers, 60, pp. 73-81 Bank for International Settlements.

South African Reserve Bank (2013) Addendum 1: Operational notice pertaining to the committed liquidity facility. South African Reserve Bank.

South African Reserve Bank (2017) Banks BA900 Returns - December 2010 to 2016. South African Reserve Bank

Standard Bank Research (2017a) South Africa: Corporate Credit - Special Report - SA REITs - A focus on key themes impacting unsecured REIT bondholders, $10^{\text {th }}$ July, Standard Bank.

Standard Bank Research (2017b) South Africa: Corporate Credit. Data for debt capital markets issuance over the period 2010 to 2016. [Email to: Murphy, CM 12/07/17 \& 10/07/17] 